\title{
РОБОТА НАД ПЕРШОДЖЕРЕЛАМИ ЯК ЗАСІБ ФОРМУВАННЯ СТІЙКИХ ЗНАНЬ І МЕТОД РОЗВИТКУ КРИТИЧНОГО МИСЛЕННЯ У СТУДЕНТІВ ВИЩОГО НАВЧАЛЬНОГО ЗАКЛАДУ
}

Мішалова О. В. Робота над першоджерелами як засіб формування стійких знань і метод розвитку критичного мислення у студентів вищого навчального закладу.

У статті розглядаються дидактичні можливості використання самостійної та аудиторної роботи над першоджерелами у викладанні гуманітарних дисциплін (філософії, історії, релігієзнавства, культурологіі). Обгрунтовується теза, що опрацювання першоджерел $є$ дієвим засобом формування стійких знань і методом розвитку критичного мислення у студентів вищої школи.

Ключові слова: першоджерело, дидактичні можливості, критичне мислення, знання.

Мишалова Е. В. Работа над первоисточниками как средство формирования устойчивых знаний и метод развития критического мышления у студентов высших учебных заведений.

В статье рассматриваются дидактические возможности использования самостоятельной и аудиторной работы над первоисточниками в преподавании гуманитарных дисциплин (философии, истории, религиоведения, культурологии). Обосновывается положение, что обработка первоисточников является эффективным средством формирования устойчивых знаний и методом развития критического мышления у студентов высших учебных заведений.

Ключевые слова: первоисточник, дидактические возможности, критическое мышление, знания.

Mishalova O. V. Processing of original sources as an effective method of forming longlasting knowledge and developing critical thinking skills in university students.

The paper deals with didactic possibilities of using individual and instructor-led processing of original sources in teaching human sciences (philosophy, history, religion studies, culture studies). The claim is that processing of original sources is as an effective method of forming long-lasting knowledge and developing critical thinking skills in university students.

Key words: original source, didactic possibilities, critical thinking skills, knowledge.

Сучасний етап розвитку світу, пов'язаний із настанням доби інформаційного суспільства, становить якісно новий етап розвитку світової цивілізації. 3 середини 90-х рр. ХХ ст., коли інтернет зі спеціалізованої воєнної мережі фактично перетворився на мережу глобальну - Мережу з великої букви - інформаційне суспільство із цікавої гіпотези неочікувано перетворилося на реальність. Інформаційні технології нині становлять невід'ємний складник всього виробничого життя і можуть бути порівнювані 3 паровою машиною XVIII ст., яка істотно змінила хід історичного процесу. Усього за одне століття, як зазначає М.Моїсєєв у своїй роботі «Інформаційне суспільство: можливість і реальність» (Москва, 2004) повністю змінилася вся система життєвих стандартів людини; на сучасному етапі відбуваються подібні процеси, однак зовсім іншими (набагато білыш швидкими) стали темпи змін умов нашого життя. 
Безумовно, позитивним явищем у цих широкомасштабних перетвореннях $\epsilon$ вільний доступ до багатьох інформаційних ресурсів, доступність інформації з будьякого питання і в будь-якій кількості в мережі інтернет, що звичайно дозволяє долучитися до неї більшій кількості людей, аніж це було можливим ще два-три десятиліття назад. Водночас нині ми можемо говорити не лише про позитивні наслідки інформатизації нашого життя. Надзвичайно швидкий темп життя і неймовірно насичене інформацією різного роду середовище призводить до того, що в більшості випадків втрачається якість оброблення цієї інформації, відповідно знижується якість самої інформації. Іншими словами, людина просто не має достатньо часу на їі осмислення, звернення до іiі першоджерел, що призводить до кризи духовної культури або, за словами Ф. Михайлова, до «масового поверхового всезнайства», коли заманливі своєю доступністю поетичні, музикальні i художні сурогати вищих емоцій повсюдно витісняють культуру кожного народу, що має глибокі корені в товщі століть, підточуючи іiі елітарні вершини [8, с. 258]. Прикладами можуть слугувати наявні в будьякому книжковому магазині брошури з назвами «Конфуцій за 90 хвилин» або «Платон за 90 хвилин».

До цього слід додати також ширення свого роду скептицизму щодо інформаційної продукції, який, за висновками соціологів, грунтується на «синдромі недовіри» до всього офіційного в посттоталітарних суспільствах, до яких належить і український соціум.

У результаті ми отримуємо досить складну ситуацію щодо гуманітарної освіченості як суспільства загалом, так і молоді зокрема. Виходом із цієї складної ситуації, на нашу думку, є більш активне звернення до роботи з першоджерелами на семінарах з гуманітарних дисциплін - філософії, історії, релігієзнавства, культурології, етики - у вищих навчальних закладах. Тому метою статmі є теоретичний розгляд форм і методів роботи з першоджерелами у викладанні гуманітарних дисциплін у вищому навчальному закладі.

Насамперед, важливо зазначити, що під джерелом знань, як вказує у своїй праці «Лабораторно-практичні роботи у викладанні історії України» К. Баханов, можна розуміти все, звідки студент може здобувати інформацію 3 навчального предмета: підручники, довідники, науково-популярна література, матеріали преси, тобто все, що створене в процесі людської діяльності і містить у собі інформацію про багатогранність суспільного життя (Київ, 1996). Активне використання джерел в процесі навчання передусім характерне для історичної науки, де їх поділяють на «первинні» (першоджерела або історичні документи) та «вторинні» (підручник, додаткова i науково-популярна література). Зазначений поділ на первинні (першоджерела) та вторинні джерела доцільно розповсюдити й на інші гуманітарні дисципліни. Слід підкреслити, що в сучасній філософії освіти історію цінують саме через методику історичного пізнання.

Дослідженню питання опрацювання першоджерел у викладанні i вивченні історичної науки присвячено значну кількість методичних робіт, докладний розгляд яких не входить до завдань нашого дослідження. Тим не менш, важливо згадати фундаментальні праці К. Баханова, у якій грунтовно розглядається методика проведення лабораторно-практичних занять 3 історії, зокрема 3 використанням історичних першоджерел («Лабораторно-практичні роботи у викладанні історії України», Київ, 1996), та Р.Страдлінга, присвячена вивченню методик викладання історії Свропи в підручниках і навчальних посібниках 3 історії у середній та вищій школі різних європейських країн [11]. На окремі методи і методики опрацювання першоджерела 
звертають увагу у своїх роботах Д. Десятов, Л. Задорожна, Т. Ковбасюк, О. Святокум, О. Турянська та інші $[3 ; 4 ; 6 ; 10 ; 13]$.

Робота над першоджерелом $є$ важливим складником у викладанні та вивченні всього комплексу гуманітарних наук у вищій школі, оскільки текст, зокремасловесний текст, за влучним визначенням М. Бахтіна, $є$ первинною даністю для всіх гуманітарних дисциплін («Естетика словесної творчості», Москва, 1979). Опрацювання першоджерела ілюструє, підтверджує та доповнює вже набуті знання 3 певної теми, а також становить засіб конкретизації навчального матеріалу, який має на меті поглибити розуміння студентами основних ідей, концепцій $\mathrm{i}$ теорії філософського, культурологічного та релігієзнавчого знання. Усвідомлюючи різноманіття дидактичних можливостей, які пропонує робота над першоджерелами, ми зосередимо свою увагу лише на двох важливих аспектах. Організоване й систематичне опрацювання першоджерел у процесі викладання і навчання у вищій школі, по-перше, формує стійкі знання з дисципліни, по-друге, розвиває критичне мислення студентів вищого навчального закладу.

У процесі організації самостійної або аудиторної, групової чи колективної роботи студентів над першоджерелами відбувається об'єднання таких компонентів змісту навчання, як: 1) інформаційного (студенти отримують знання 3 тексту джерела); 2) операційного (процес роботи студентів над першоджерелом $\epsilon$ низка операційних процедур, які, розвивають відповідні розумові вміння - аналіз, синтез, осмислення, тлумачення); 3) творчо-пошукового (формування досвіду у виконанні творчих пошукових завдань, пошуково-дослідницької практичної діяльності); 4) ціннісносмислового (досвід емоційно-ціннісного ставлення до матеріалу першоджерела) [13, с. 27]. Це створює сприятливі умови для формування у студентів стійких знань 3 предмета.

Продуктивному формуванню грунтовних знань, умінь і навичок у роботі над першоджерелами істотно допомагає той факт, що першоджерело $є$ вагомим засобом мотивації навчальної діяльності студентів вищої школи. Загалом у психології мотивацію поділяють на зовнішню, зумовлену відповідно зовнішніми умовами й обставинами, i внутрішню, пов'язану 3 особистісними потребами, бажаннями. Остання має на меті зробити вивчення предмета захопливим дослідженням ідей та ціннісних систем минулого з позицій багатоперспективності і полікультурності, у центрі якого перебуває людина, яка розв'язує «вічні» проблеми суспільного життя. Реалізація індивідом власних здібностей і потенцій - основна мотивуюча сила людської поведінки.

Важливим аспектом у роботі над першоджерелами $\epsilon$ добір i розроблення комплекту першоджерел. Останні обов'язково повинні відповідати таким методичним вимогам: а) відповідати цілям і завданням навчання; б) бути органічно пов'язаними із програмним матеріалом дисципліни; в) відображати основні, найбільш типові ідеї, факти і події; г) бути цікавим і доступним студентам за змістом і обсягом; д) здійснювати на студентів позитивний емоційний вплив; є) мати наукові і літературні переваги [3, с. 3-4].

Особливо слід звернути увагу на умови ефективної роботи над першоджерелами. Насамперед, це системність, адаптованість першоджерела до сприйняття його змісту студентами, супровід тексту першоджерела поясненням відповідних термінів і понять, формулювання питань до тексту першоджерела, спрямованих на більш глибоке його осмислення студентами. Велике значення має також інструктаж викладача, у процесі якого пояснюється мета і особливості самостійної роботи, даються завдання для неї і залежно від того, наскільки студент володіє необхідними вміннями і навичками, вказується або не вказується спосіб виконання завдання. 
У зв’язку з цим цікавою ідеєю, на нашу думку, є ідея створення спеціальних документально-методичних комплексів, запропонована І. Власенко. Основою організації роботи з документально-методичним комплексом є суперечності, закладені у змісті першоджерел, проблемні питання і завдання до них. Теоретичною базою технології навчання з використанням документально-методичних комплексів $є$ модель навчання В. Гальперіна, ключовим елементом якої є «дія міркування» [2, с. 12].

Робота над першоджерелами $є$ насамперед самостійною роботою. Традиційно в навчальній практиці застосовуються такі прийоми, як конспектування та складання тез. Ці види самостійної роботи досить прості і доступні для студентів. Водночас, вони мають неабияке значення для успішного навчання, оскільки формують уміння і навички осмислення тексту друкованих джерел, ведення записів, забезпечують активну роботу всіх без винятку студентів, привчають їх користуватися власними нотатками, конспектами і тезами. Крім того, конспектування та складання тез полегшують контроль за результатами роботи кожного студента, а також розширюють можливості диференційного підходу до навчання [4, с. 9]. Важливий дидактичний потенціал таких видів роботи над першоджерелом, як конспектування і складання тез, полягає в тому, що вони готують учнів до більш складних форм роботи.

Найбільш складною і відповідальною є робота з пізнавальними завданнями різного рівня складності. Останні можуть бути кількох видів: завдання до кожного окремого першоджерела, завдання до всього документального матеріалу, запропонованого до теми, що вивчається, завдання узагальнюючого практичного спрямування (складання таблиць або схем) [4, с. 10$]$.

Основними критеріями сформованості вмінь самостійної роботи студентів можна вважати: 1) планування самостійної роботи і передбачення проміжного і кінцевого контролю за своєю діяльністю; 2) логічний аналіз навчального матеріалу; 3) систематизація матеріалу та розроблення схеми аргументованого доведення.

Самостійна робота є основою і водночас умовою для успішної аудиторної роботи над першоджерелом. Аудиторне опрацювання першоджерела доцільно проводити у формі групової кооперативної роботи. Організовуючи кооперативну навчальну діяльність, викладач має змогу керувати роботою кожного студента не безпосередньо, а за допомогою завдання, запропонованого групі загалом, завдяки цьому стосунки між викладачем і студентом набувають ознак співпраці. У групи можуть бути об'єднані студенти 3 різним рівнем навчальних можливостей, для чого можуть бути передбачені як спільні, так і диференційовані завдання. Правильно організована навчальна діяльність у групах активізує студентів, підвищує результативність навчання, сприяє вихованню самостійності, розвиває в учнів навички культури ведення діалогу [10, с. 27].

Отже, опрацювання першоджерел як вид самостійної та аудиторної роботи, слугує вагомим засобом активізації пізнавальної діяльності студентів, створюючи умови для продуктивного формування стійких знань з гуманітарних дисциплін.

Робота над першоджерелами $є$ також засобом розвитку критичного мислення. Затребуваність критичного типу мислення зумовлюється двома визначальними чинниками сучасного суспільного життя. По-перше, особливостями інформаційного суспільства, яке характеризується змінами, що постійно прискорюються. Інформація набуває якісно нових функцій, які можна порівняти 3 базисними функціями землеволодіння в епоху Середньовіччя або капіталу в Новий час. Інформаційна революція містить вагомий антропологічний складник, що передбачає вдосконалення не лише техніки і технологій, але й людини, передусім іiі мислення. По-друге, критичне мислення - це вагомий чинник існування і формування демократичного суспільства, оскільки в демократичному суспільстві на перше місце виходить здатність та готовність 
оцінювати ситуацію критично. Оскільки цивілізований спір - природний спосіб відносин двох або більшого числа вільних особистостей щодо питань із сфери перетину їхніх інтересів, остільки критичне мислення виявляється необхідною умовою досягнення успіху у вільному демократичному суспільстві [12, с. 28].

Питання розвитку критичного мислення є нині досить актуальним в дидактичній літературі. Так, на думку М. Вайнштайна, критичне мислення постає як нестандартне мислення, яке не може грунтуватися на алгоритмах чи інших механічних процедурах. До нього вдаються у тих випадках, коли необхідно зважити та оцінити альтернативи, а також коли потрібні оцінка пріоритетів і визначення достовірності та доречності [1, c. 50].

Розвиток критичного мислення як нагальну потребу для життя в сучасному світі розглядав у своїй концепції освіти М. Ліпман. На його думку, «освіта як дослідження» («education as inquiry») гармонійно поєднує дві принципово важливі для освіти ціліпередачу знань i здійснення дослідження задля встановлення істини. Критичне мислення він розглядав як складне уміння, що дозволяє правильно розв'язувати широке коло практичних проблем у будь-якій професійній діяльності (архітектора, юриста, лікаря), у людських взаємовідносинах (ситуації морального вибору), у науковій діяльності та повсякденному житті. Отже, критичне мислення розглядалося М. Ліпманом як навчання вмінню розмірковувати (див. [12, с. 27]). Серед основних ознак критичного мислення він вирізняє такі: по-перше, критичне мислення - це мислення, спрямоване на формулювання можливих суджень (іншими словами, це мислення прикладне або практичне, яке використовує теоретичні знання, щоб досягти рішень, компромісів та інших типів суджень); по-друге, це мислення, яке керується критеріями; по-третє, це мислення, яке $\epsilon$ самокеруючим (передбачає пошук можливостей здійснення помилок і шляхів їх виправлення); по-четверте, це мислення, яке залежить від ситуації (вміння враховувати індивідуальність кожної ситуації) [7, c. 62-63].

Психологічно критичне мислення грунтується на прагненні до творчого пошуку, прагненні до знань. Критичне мислення - це мислення, що характеризується самовдосконаленням. Такий тип мислення є науковим за своєю суттю. Саме наукове мислення, яке постійно самовдосконалюється, забезпечує науково-технічний та суспільний прогрес [12, с. 30]. Критичний мислитель перебуває в процесі неперервного дослідження, і важливим є саме те, що і незалежні критерії, які він використовує, i процесуальні норми, що характеризують його аргументацію, відкриті для критики та переоцінки [1, с. 50].

Розвиток критичного мислення становить процес, у результаті якого актуалізуються такі природні якості людини як допитливість, сприйнятливість, самостійність і впевненість у своїх силах, комунікабельність і вміння вільно висловлювати свої думки. Студенти, які володіють навичками критичного мислення, здатні самостійно знаходити розв'язання навчальних проблем, доводять слушність рішення розумними й обгрунтованими доказами. При цьому, вони також добре усвідомлюють, що можливими є й інші шляхи розв'язання проблеми [5].

Розвиток критичного мислення є невід’ємним від процесу розвитку ще однієї надзвичайно важливої якості мислення студентів вищого навчального закладу i майбутніх спеціалістів - творчості мислення. Не виокремлено якихось особливих рис творчого мислення, які б не були одночасно синонімічними самому творчому мисленню. Однак все ж можна вирізнити певні параметри: образність, творчість, продуктивність, незалежність, цілісність, самоневдоволеність [7, с. 63]. 
У методичній літературі вирізняють такі загальні ознаки творчого характеру мислення: 1) оригінальність думки, здатність давати відповіді, які істотно відрізняються від звичних; 2) виконання розумових дій свідомо, а не випадково; 3) здатність виявляти нові, незвичні функції об'єкта чи його частини; 4) гнучкість мислення, коли людина може легко відхилятися від звичного способу виконання завдання, долаючи стереотипи [10, с. 27].

Найважливішою умовою для розвитку критичного мислення $\epsilon$ створення проблемних ситуацій під час навчання. Саме розв'язання проблем забезпечує опанування принципів, стратегій і процедур критичного мислення [12, с. 31]. Найбільші дидактичні можливості для постановки та розв'язання проблемних завдань в опрацюванні текстів першоджерел пропонують ігрові методи навчання.

Ігрові методи навчання науковці відносять до нетрадиційних активних імітаційних методів, вони є надзвичайно різноплановими і кожен 3 них, як правило, спрямований на вироблення певної розумової навички у студентів. Ігрові методи навчання характеризують такі особливості: наявність ігрових моделей об'єкта, процесу або діяльності; активізація мислення і поведінки студента; високий ступінь їх задіяності у навчальному процесі; обов'язковість взаємодії студентів між собою і викладачем; посилення емоційності і творчий характер заняття; самостійність у прийнятті рішення [9, с. 18].

До ігрових методів навчання, які можуть бути використаними в роботі над першоджерелами, слід віднести такі: по-перше, ігри-вправи, які можуть проводитися на уроці, входити до складу самостійної роботи (не потребують тривалої підготовки і займають порівняно небагато аудиторного робочого часу); по-друге, ігрова дискусія, яка спрямована на формування вміння виявляти відмінності в розумінні складної проблеми або питання і шляхом товариської суперечки вирішувати їх, доходячи в результаті до спільної точки зору (потребує використання першоджерел, які містять дискусійні положення); по-третє, метод ігрової ситуації, в основі якої лежить проблемна ситуація (мета - навчити студентів встановлювати зв'язки між теоретичним i практичним матеріалом $з$ теми, сформувати вміння аналізувати, робити висновки, приймати рішення у нестандартних ситуаціях); по-четверте, повчально-рольова гра, яка дозволяє відтворити практично будь-яку ситуацію в «ролях», що дозволяє краще зрозуміти психологію людей, стати на їхнє місце, з'ясувати і зрозуміти мотиви, які спонукали їх до прийняття рішення [9, с. 18-20].

Отже, опрацювання першоджерел, як вид самостійної та аудиторної роботи студентів вищої школи, також $є$ потужним засобом розвитку критичного творчого мислення, особливо в поєднанні $з$ ігровими методами навчання, дозволяє створювати сприятливі умови не лише для більш швидкого засвоєння знань, але й для формування вміння студентів приймати власне рішення у складних нестандартних проблемних ситуаціях.

У реаліях сучасного інформаційного світу з його надзвичайно швидкими темпами розвитку і змін ознайомлення з першоджерелами світової філософської, історичної, релігієзнавчої, етичної та культурологічної думки залишається вагомим складником загальної освіти всебічно розвинутої особистості, тому залучення різних за характером методів і прийомів роботи над першоджерелами також $\epsilon$ доволі актуальним i перспективним напрямом дослідження в методиці викладання і навчання гуманітарних дисциплін.

\section{Література}

1. Вайнштейн М. Критичне мислення як основа демократичного навчання / Марк Вайнштейн // Рідна школа. - 2001. - № 4. - С. 49-51. 2. Власенко І. І. Документально- 
методичний комплекс як засіб розвитку творчого мислення / I. I. Власенко // Історія та правознавство. - 2012. - № 19-21. - С. 11-14. 3. Десятов Д. Л. Деякі аспекти використання історичного документа/ Дмитро Леонідович Десятов// Історія та правознавство. - 2006. - № 26. - С. 3-7. 4. Задорожна Л. Навчити працювати самостійно (Інтеграційний метод роботи 3 історичними документами)/ Лілія Задорожна // Історія в школах України. - 2004. - № 5. - С. 7-10. 5. Киселева Ю. В. К проблеме формирования критического мышления студента вуза [Електронный ресурс]/ Ю. В. Киселева // Credo New. - 2012. -№1. - Режим доступу: http://www.intelros.ru/readroom/credo_new/credo-new-2012-1/13145-.html б. Ковбасюк Т. Традиції та новації у використанні писемних джерел на уроках історії України / Тетяна Ковбасюк // Історія в школах України. - 2008. - № 11-12. - С. 46-48. 7. Ліпмен М. Значення філософії для демократії обговорення / Мет’ю Ліпмен // Рідна школа. - 2001. № 4. - С. 61-64. 8. Михайлов Ф. Т. Культурология как основание общего человековедения / Феликс Трофимович Михайлов //. Михайлов Ф. Т Избранное. - М. : Индрик, 2001. - С. 257-400. 9. Саюк В. Ігрові методи та їх дидактичне значення/ Валентина Саюк// Рідна школа. - 2001. - № 4. - С. 18-20. 10. Святокум О. Застосування колективних форм у роботі з текстовими джерелами в основній школі / Оксана Святокум // Історія в сучасній школі. - 2013. - № 1. - С. 27-33. 11. Страдлинг Р. Преподавание истории Европы XX века: [монографія] / Роберт Страдлинг.- Страсбург : Совет Европы, - 2002. - 289 с. 12. Терно С. Світ критичного мислення: образ та мімікрія / Сергій Терно// Історія в сучасній школі. - 2012. - № 7-8. - С. 27-39. 13. Турянська О. Методи особистісно-орієнтованого навчання в школі/ Ольга Турянська // Історія в шк. України. - 2002. - № 1. - С. 27-32.

\section{СУТНІСТЬ І СТРУКТУРА ГОТОВНОСТІ МАЙБУТНЬОГО ВЧИТЕЛЯ ПРИРОДНИЧО-МАТЕМАТИЧНИХ ДИСЦИПЛІН ДО ПЕДАГОГІЧНОГО ПРОЕКТУВАННЯ ЗАСОБАМИ ІНФОРМАЦІЙНИХ ТЕХНОЛОГІЙ}

Перець О. Б. Сутність і структура готовності майбутнього вчителя природничоматематичних дисциплін до педагогічного проектування засобами інформаційних технологій.

У статті проаналізовано проблему готовності майбутнього вчителя природничоматематичних дисциплін до педагогічного проектування засобами інформаційних технологій. Визначено й обгрунтовано поняття означеної готовності та схарактеризовано іiї компоненти з відповідними елементами.

Ключові слова: підготовка, готовність, готовність майбутнього вчителя природничо-математичних дисциплін до педагогічного проектування, педагогічне проектування, засоби інформаційних технологій.

Перец О. Б. Сущность и структура готовности будущего учителя естественноматематических дисциплин к педагогическому проектированию средствами информационных технологий.

В статье проанализирована проблема готовности будущего учителя естественноматематических дисциплин к педагогическому проектированию средствами информационных технологий. Определено и обосновано понятие заявленной готовности, охарактеризованы ее компоненты с соответствующими элементами. 